\title{
5 Modality and Evidentiality
}

\subsection{Introductory Remarks}

Modality is a semantic category, which expresses the attitude of the author of the text, as well as their assessment of the contents of the utterance or the course of action (Matthews 1997, 228; Palmer 2001, 1).

Depending on the text author's attitude to the contents of the utterance and the course of action, we can distinguish two subtypes of modality (Palmer 2001, 4-7):

1. deontic modality;

2. epistemic modality.

Evidentiality is a particular semantic category, which unites the language means that contain a reference to the source of information and the assessment of the contents of the utterance (Wiemer 2007; Wiemer 2010, 198; see also Holvoet 2001, 111).

In Latvian, the mood of the verb can express both deontic and epistemic modality as well as an evidential meaning.

It must be noted that the combination of several modal meanings, as is done in Latvian, is not an exception; it is widely attested in the languages of the world (see Kalnača 2011, 2012). For instance, van der Auwera et al. (2005, 252-258) describe the so-called combination of situational and epistemic modalities to express the meaning of necessity and possibility where the situational modality is non-epistemic, i.e., deontic and dynamic modality. In the same spirit, Bybee and Fleischman (1995, 5-6) claim that one and the same linguistic form can express both epistemic and deontic modalities (see also Nuyts 2005, 16-17).

\subsection{Deontic Modality}

Deontic modality points to the text author's attitude towards the proceedings of the situation, in the form of an order, prohibition, or suggestion (Palmer 2001, 9-10).

Deontic modality in Latvian is mostly connected with the imperative mood, which paradigmatically expresses an assessment of the action proceedings, aimed at influencing the addressee of the text to achieve the purpose of the author of the text in the particular action, for example:

\begin{tabular}{|c|c|c|c|}
\hline $\begin{array}{l}\text { Abonē } \\
\text { subscribe.IMP.2SG }\end{array}$ & $\begin{array}{l}\text { un } \\
\text { and }\end{array}$ & $\begin{array}{l}\text { laimē } \\
\text { win.IMP.2SG }\end{array}$ & $\begin{array}{l}\text { žurnālus! } \\
\text { magazine.ACC.PL.M }\end{array}$ \\
\hline
\end{tabular}

(Mājas Viesis) 
Traditionally, deontic modality is related to the imperative mood in cases where the speaker wants to influence the addressee using a certain degree of power (Palmer 2001, 80). However, the imperative mood is not the only Latvian form encoding the meaning of root modality. In specific contexts or communicative situations root modal reading can be expressed by other moods, modal verbs, and other expressive means (for more on these modal meanings and the means of conveying such meanings see Bybee, Fleischmann 1995, 5; Nuyts 2005, 14-15; Nuyts, Byloo, Diepeveen 2005, 11-12; De Haan 2006, 32-41).

Thus next to the imperative mood, in particular circumstances in Latvian, deontic modality can also be expressed using the debitive mood, for example:

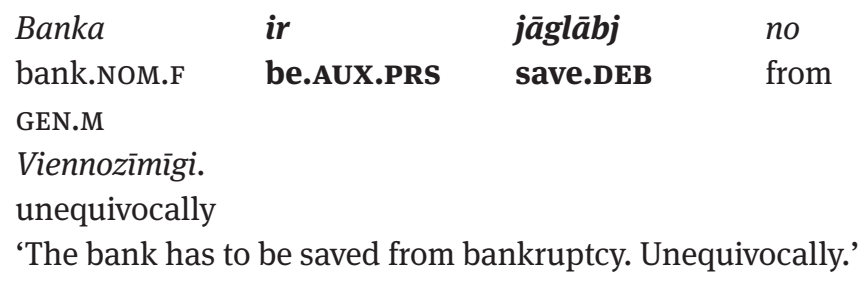

(Puaro)

Comparing the deontic modality expressed by the debitive and imperative moods, the difference in meaning is marked in that the imperative always denotes some request or an order said directly to the addressee. The debitive, on the other hand, denotes an action to which the speaker or somebody else is committed, as Portner argues, something we have to do because it is an obligation (Portner 2007, 380-381, see also Lokmane \& Kalnača 2014).

Deontic modality in a particular contextual use can be observed also in the indicative mood, if it is used in the function of the imperative mood:

1. indicative mood present indefinite, expressing an invitation:

Tad ejam rodien pusdienās!
then go.PRS.1PL today dinner.LOC.PL.F
'Then let us have dinner today!'

\section{2. indicative mood future indefinite}

a) expressing a polite request, for example:

$$
\begin{array}{lllll}
\text { "Kundzit, } & j u ̄ s & \text { ar } & \text { to } & \text { grozu, } \\
\text { lady.Voc.F } & \text { you } & \text { with } & \text { that.ACC.M } & \text { basket.ACC.M }
\end{array}
$$




\section{panāksit tuvāk!” \\ come.FUT.2PL closer}

Salutaurs uzsauca

'You, madame, with the basket, come closer!' Salutaurs called out.'

(Eglīis)

b) expressing a categorical demand; the sentence usually contains the ethical dative - the personal pronoun in the dative marking the author of the text, for example:

$\begin{array}{lllll}\text { Tu } & \text { man } & \text { pieskatīsi } & \text { šos } & \text { te! } \\ \text { you } & \underline{\text { I.DAT }} & \text { look.FUT.2sG } & \text { these.ACC.PL.M } & \text { here }\end{array}$

- Bradinš labdienas vietā uzsauc Kūlam, uz Eldu un bērniem rādīdams.

'You will look after them for me! - Bradiṇš called out to Kūla, pointing to Elda and the children.'

(Janovskis)

\subsection{Epistemic Modality}

The epistemic modality points out the text author's attitude towards the contents of the utterance (judgement, assertion), expressing a need, possibility, or probability (Palmer 2001, 8-9).

In Latvian, epistemic modality is usually connected with the conditional mood, as the semantics of the mood already involve a reference to a possible future oriented action, for example:

$\begin{array}{lllll}\text { Lai } & \text { uzņemtos } & \text { amatu, } & \text { vajag } & \text { dūšu. } \\ \text { if } & \text { accept.cond } & \text { post.ACC.M } & \text { need.PRs.3 } & \text { courage.ACC.F } \\ \text { 'To accept the post, you need courage.' } & & \end{array}$

(Skujinš̌)

In Latvian, epistemic modality can be expressed also by the indicative, oblique, or debitive moods, for example:

a. Indicative mood (usually in the form of the future indefinite or future perfect)

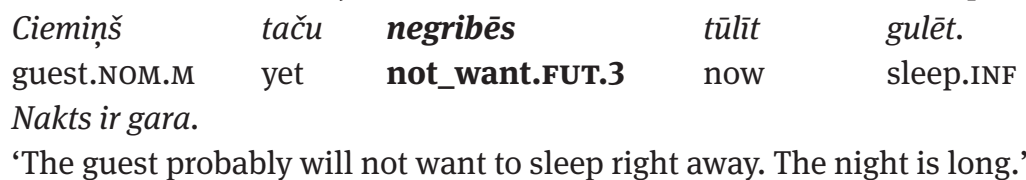

(Sodums) 
b. Oblique mood

Un tāda

esot

draudzene!

and such.NOM.F

be.COP.OBL.PRS

friend.NOM.F

Esmu sašutis bez gala.

'And she would call herself a friend! I am completely disgusted!'

(G)

c. Debitive mood

$\begin{array}{llll}\text { Tur } & \text { kaut kam } & \text { ir } & \text { jābūt. } \\ \text { there } & \text { something.DAT } & \text { be.AUX.PRS } & \text { be.DEB }\end{array}$

'Something must be there.'

The epistemic modality is not typical of the debitive mood, but it possible usually with the stative verbs būt 'to be', sēdèt 'to sit', gulēt 'to sleep', stāvēt 'to stand' (in more detail see Lokmane \& Kalnača 2014).

\subsection{Evidentiality}

Evidentiality is a semantic category, which unites the means of language that include a reference to the source of information as well as an assessment of the contents of the utterance (Wiemer 2007; Wiemer 2010, 198; see also Holvoet 2001, 111).

Latvian linguistics also has recorded another popular opinion in which evidentiality is part of the modality (Skujinga et al. 2007, 112; see also Palmer 2001, 8; Usonienè 2004).

Regardless of whether evidentiality is considered to be a subtype of modality or a specific semantic category, the means of its expression - either grammatical or non-grammatical (i.e., lexical) - can be found in every language (Usonienè 2004; Kozinceva 2007, 13-36; Chojnicka 2009, 41, see also Kalnača 2007, 2010). In addition, Plungian $(2000,325)$ rejects the existence of evidential modality as such, because the semantics of quotations cannot be considered a modality (see also Matthews 1997, 120).

Latvian (alongside Lithuanian, Estonian, Livonian, and other languages) is one of relatively few world languages, which has developed a particular mood - the oblique mood - for the expression of evidentiality (Plungian 2001; Aikhenvald 2004; Krautmane 2006). Therefore, when the text author is not the author of the information, Latvian mostly uses the oblique mood (Kalme \& Smiltniece 2001, 245; Holvoet 2001, 112; Paegle 2003, 114-115). The fact that the information has been obtained from a different source, is usually marked by verbum dicendi in the first part of the composite sentence. 
As was mentioned before, evidentiality is marked by the oblique mood in Latvian (Holvoet 2007, 80-105), for example:

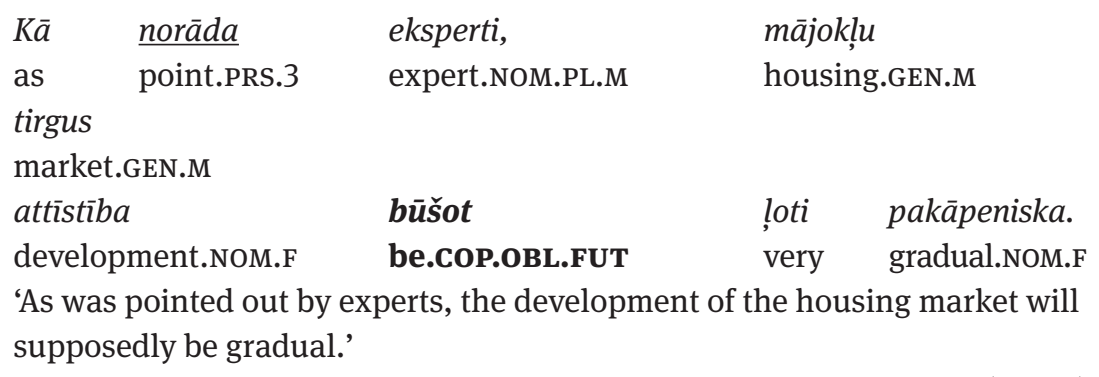

(Diena)

Evidentiality, that is a reported need, is also expressed by the debitive mood oblique submood, which is often used in spoken language, for example:

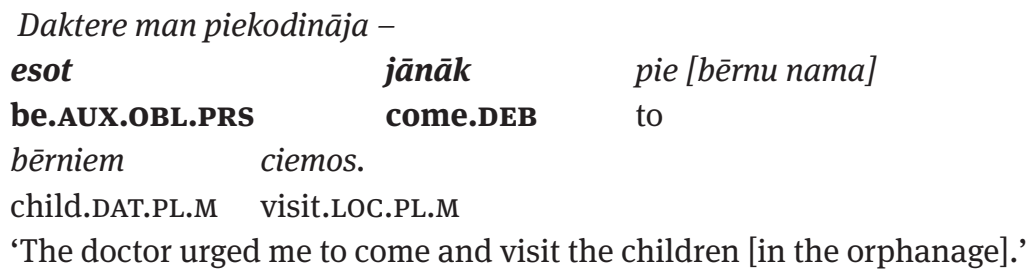

Evidential semantics are also typical of the indicative mood in the function of the oblique mood. This usually occurs in a composite sentence with a verbum dicendi in one of its clauses, for example:

(5.10) Vēl pirms ierašanās Atēnās laika ziṇas vēstīja,

$\begin{array}{llll}k a & \text { tur } & \text { list } & \text { lietus. } \\ \text { that } & \text { there } & \text { rain.PRS.3 } & \text { rain.NOM.M }\end{array}$

'Even before arriving in Athens, the weather news was reporting that it was raining there.'

(Mājas Viesis)

\subsection{Combining Evidentiality and Modality}

As can be seen from the description of the semantics of modality in Latvian, some moods are polyfunctional and, depending on the context, can express a deontic, epistemic, or evidential meaning. The indicative mood as the unmarked element 
of the opposition of different moods, is the most polyfunctional. The oblique and debitive moods also can be polyfunctional.

The oblique mood, depending on the particular use, can express evidential as well as epistemic semantics. The evidential and epistemic meanings used in the oblique mood can also combine in cases where the author wishes to distance themselves from the contents of the text or to express their doubts about those contents, for example, in the title of an online source:

$\begin{array}{llll}\begin{array}{l}\text { Valsts } \\ \text { state.Nom.F }\end{array} & \text { pati } & \text { gribot } & \text { izputināt } \\ \text { banku? } & & \\ \text { bank.ACc } & & \\ \text { 'They say the state itself wants to destroy the bank?' }\end{array}$

(TVNET)

The oblique mood points out that the text author has heard this utterance from others but does not agree with it; the interrogative form is expressing the same attitude. Thus one utterance can syncretically express both evidential as well as epistemic semantics.

From the point of view of the typology of the modality, the classification of the debitive mood causes problems. In contrast to other moods, the debitive mood can express both deontic and epistemic modality depending on the particular use (see more in Holvoet 2007, 173-195). Nevertheless, one has to admit that most cases of debitive mood use are connected with deontic modality, while epistemic modality is possible mostly in the sentences containing stative verbs (see also Lokmane \& Kalnača 2014).

The semantics of the submoods of the debitive mood are not homogeneous. For example, the oblique submood of the debitive mood can syncretically express at least two types of modal meaning:

1. evidentiality + epistemic modality, if the text author reports a well-grounded assessment of some fact expressed in the debitive mood (epistemic judgement):

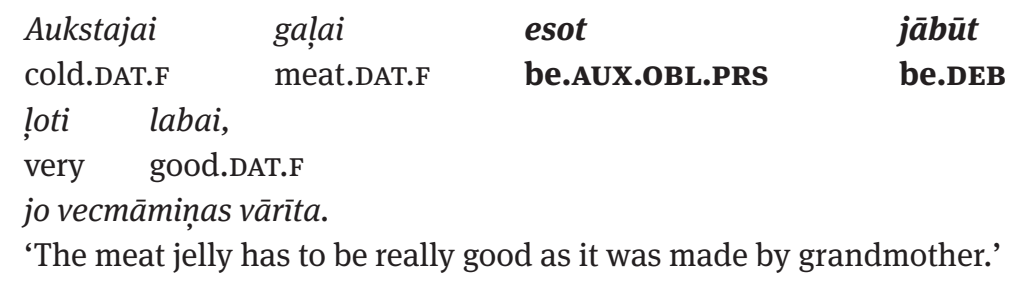


2. evidentiality + deontic modality in the case of a reported need, see example (5.9).

The conditional submood of the debitive mood expresses a weakened deontic modality, as the auxiliary verb used by the text author points to the author's wish to distance themselves from the need for the action or is not sure about the the need itself, for example:

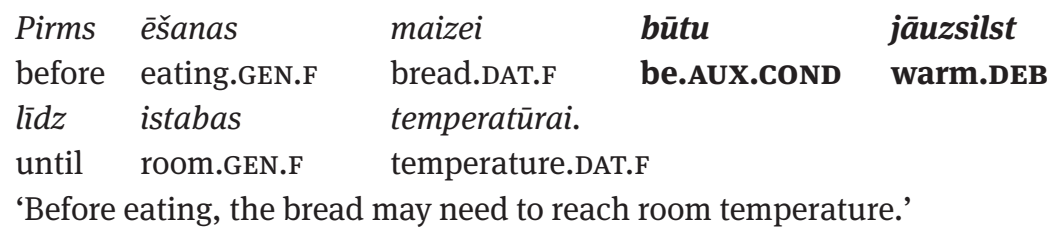

